\title{
Building a Self-Reliant Economy and Its Great Vitality: The Case of DPRK
}

\section{Un-Chol Kim, Chol Hwang}

Faculty of Economics, Kim Il Sung University, Pyongyang, Democratic People's Republic of Korea

Email address:

ryongnam18@ahoo.com (Un-Chol K.)

\section{To cite this article:}

Un-Chol Kim, Chol Hwang. Building a Self-Reliant Economy and Its Great Vitality: The Case of DPRK. International Journal of Economy, Energy and Environment. Vol. 2, No. 1, 2017, pp. 7-12. doi: 10.11648/j.ijeee.20170201.12

Received: August 18, 2016; Accepted: January 4, 2017; Published: January 18, 2017

\begin{abstract}
As the world people know, Korea is the homeland of the Juche idea which is a great man-centred philosophical thought. The Juche idea initiated by President Kim Il Sung is a thought that man is the master of everything and decides everything, that is, a thought that man is the master of his own destiny and has the power to carve out his own destiny. By applying the fundamental principle of the Juche idea in the sector of economic construction, the Workers' Party of Korea (WPK) put forth the line of building a self-reliant economy and has wisely led the struggle for the its implementation. By advancing the great line of building an independent national economy for the first time in history and guiding its implementation wisely, the WPK set up a world-famous pattern of building a socialist economy and a model of self-reliance.
\end{abstract}

Keywords: Self-Reliant Economy, Independent National Economy, Self-Supporting Economy, Economic Building in DPRK

\section{Introduction}

Building an independent national economy means building an economy which is free from dependence on others and which stands on its own feet, an economy which serves one's own people and develops on the strength of the resources of one's own country and by the efforts of one's own people. The WPK's line of building an independent national economy is the one of consolidating the foundations of a certain nation's own economy in economic building and relying on the foundations to hasten the overall economic construction. [2, 8, 9]

There are different kinds of economy around the world; some countries, typically those in the Middle East, put emphasis on extraction and processing of crude oil, some pursue economic development centred on developing tourist resources and relevant services, and yet some others push economic development by giving priority to the production of coffee or tea. Unlike these economies, a self-reliant economy is the one of laying a strong economic foundation of one's own and using it to satisfy most of the needs of the nation's economic development and the people's living.

Our country has firmly maintained President Kim Il Sung's line of building an independent national economy as the lifeline and implemented it thoroughly in economic construction. [7]
In order to build a self-reliant economy our country has attached primary attention to the effort to set up a structure of an independent economy. What is characteristic of such a structure is that it is diversified and comprehensive. The structure of a diversified and comprehensive economy is the one that is equipped with enough production sectors to largely satisfy various material needs of the country and the people, a complete structure that has the whole cycle of manufacture from production of materials to the finishing of products. Only when a diversified and comprehensive economic structure is established, will it be possible to turn out means of production and consumer goods enough to meet the demand in making the country prosperous and improving the living standard. $[1,3,5]$

Our country thoroughly implemented the basic line of socialist economic construction, which demands that the development of heavy industry be given precedence while light industry and agriculture be developed simultaneously, and has consistently pursued the basic line of economic construction in the Songun era, a higher version of the former policy suited to the requirements of the Songun era- the new line demands the defence industry be developed on a preferential basis while light industry and agriculture be developed simultaneously. In this way the country formed and consolidated a structure of an independent economy oriented to simultaneous development of defence industry, heavy and light industry and agriculture aimed at ensuring national 
security while meeting various needs of the State and the people relying on its own resources. [1,8]

Our country has also exerted a great effort to develop the national economy by our own efforts and technology. Technical independence is essential to economic self-sufficiency. Only when supported by developed technology of one's own, will it be possible to develop the country's natural resources to effectively use and develop the national economy in a diversified and comprehensive way so as to satisfy the material needs of the State and the people. Regarding science and technology as the motive force of economic construction and the engine of development of the national economy, our country has equipped the national economy with modern technology and renovated it continuously.

Training technical cadres of the nation's own poses as an important matter in attaining economic and technical independence. The engagement of the national technical cadres will make it possible to develop the economy and technology with the nation's internal efforts. While giving precedence to development of modern science and technology and equipping and renovating the economy with modern technology uninterruptedly, our country has made steady efforts to train a large number of technical personnel. The universal free compulsory education has been considerably helpful to the rearing of able technicians, and the policy of making all people well-versed in science and technology based on the study-while-working system and the distance learning system has been carried out successfully, producing a huge number of competent personnel working efficiently in the practical fields of economic construction.

Furthermore, our country has laid solid bases to supply materials, fuel and power for the building of a self-reliant economy with the nation's own resources, thus ensuring a firm guarantee for steady development of the national economy. Depending on others for supply of materials, fuel and power, which are essential elements in economic development, is as good as leaving the lifeline of the economy under their control. In order to develop the economy on a safe and prospective footing, it is necessary to rely on one's own bases of materials, fuel and power and satisfy a larger volume of the demands for them by the country's own sources. Our country, adopting it as an iron rule to creating bases of power, materials and fuel depending on the abundant local resources, set up a self-reliant structure of the economy as a whole and has consistently strengthened it. In this way our country could successfully build and develop an independent national economy supported by its own efforts, technology and natural resources. [4]

Our people's struggle for a self-sufficient economy is inconceivable apart from the revolutionary spirit of self-reliance and the fighting spirit. Self-reliance has been a powerful motive force in the building of an independent national economy and an invariable mode of struggle in socialist economic construction. Self-reliance is, in a nutshell, a revolutionary spirit and principle of struggle to be kept by an independent human being in the endeavour to carve out his destiny by himself.

The revolutionary spirit of self-reliance and the fighting spirit were shaped in the course of obtaining arms under the leadership of Commander Kim Il Sung of the Korean People's Revolutionary Army during the anti-Japanese armed struggle. The struggle was a continuation of do-or-die battles against the formidable Japanese imperialists who were armed to the teeth. The Korean fighters had neither home front nor support of a regular armed force. Under this condition it was indescribably difficult for them to fight so many years while securing weapons, ammunitions, food, clothing and what else was needed for the armed warfare. The Korean revolutionaries were determined to win national independence with their own efforts, and yet they sometimes felt helpless in extreme difficulties and felt like turning to others for aid. In the early 1930s some revolutionaries in East Manchuria, believing they were eligible to get assistance from any communists, sent a letter to the then commander of the Soviet armed forces in the Far East asking him for a factory with the capacity of making 10000 hand-grenades a month, which they said would be a great help for them to launch a more effective fighting. To their great disappointment, however, they received no reply. The silence on the part of the Soviet people convinced them of the truth that self-reliance is the only way out and that the maximum exertion of one's own effort is the decisive factor in accelerating the revolution while others' help is of secondary importance. Now they began to approach their warfare in the revolutionary spirit of self -reliance with the belief that their own strength is the best way; they successfully manufactured grenades, pistols, rifles, bullets and even dynamite which they had thought could be made by special modern munitions factories. It was around this time that the famous story about of the "Yanji Grenade" came, the kind of grenade that struck terror into the Japanese.

The revolutionary spirit of self-reliance and the fighting spirit displayed fully in the anti-Japanese armed struggle was the progenitor of the policy of our country to hew out the righteous way of economic independence, and it has served as the driving force in its prolonged effort to win it. [2, 5]

The foundations our people laid with so much difficulty through a number of democratic reforms after national liberation, were devastated to ashes in the 1950-1953 war started by the US imperialists. Vanquishing the vicious argument of the Americans that Korea would not be able to rise up again even in 100 years, our people launched the campaign to lay down the foundations of a self-reliant economy while rehabilitating the destroyed economy in the spirit of self-reliance. When the big-power chauvinists forced our country to join the Council for Mutual Economic Assistance which was an organization for economic cooperation ruled by the former Soviet Union and East European socialist nations, our people chose to support the WPK's original basic line of economic construction on giving precedence to the development of heavy industry while developing light industry and agriculture simultaneously. They worked hard to establish a diversified and comprehensive economic structure and lay down foundations 
of a self-sufficient economy that develops on the strength of their own efforts, technology and natural resources. In the course of this they successfully accomplished the socialist industrialization in a matter of 14 years and, relying on this achievement, set a higher goal of making their national economy Juche-oriented, modern and scientifically-based, which they have been struggling to attain.

Even in the global economic upheavals due to crises of finance, oil and food, our people have consolidated their independent national economy more firmly; standing unaffected in the political cataclysm of the collapse of the global socialist system, our country held higher the banner of self-sufficiency in the economy.

During the years of building a socialist economy by dint of the force of self-reliance and self-development, our Party and people have attained all the glory that were impossible throughout the history of the nation spanning thousands of years, although they were faced with unheard-of trials and ordeals. Along the road of self-reliance and self-development our people rode Chollima shaking off the ruins of the war, and worked the miracles of manufacturing and launching artificial earth satellites and even acquiring H-bombs. [6]

\section{Building a Self-Reliant Economy Is the Direction of Economic Construction Our People Chose}

The reason for our people's decision to adopt the building of a self-reliant economy as the main direction of economic construction under the guidance of the WPK is, first of all, because economic self-sufficiency constitutes the material basis of political independence.

Economic self-sufficiency means the material guarantee of political independence. Economic subjugation leads to political subordination while self-sustenance guarantees political independence. Since our country achieved liberation from the protracted colonial rule of the Japanese imperialists, it has suffered from the US imperialists' uninterrupted moves for war and the big-power chauvinists' scheme for economic subjugation, which are inconceivably wicked. Under this condition, the matter of defending the nation's sovereignty and consolidating political independence boils down to the one of building up the nation's own defence capabilities and economic potentialities by winning economic self-sufficiency.

If we failed to be economically self-reliant and thus gave up our national independence, which we achieved through a bloody struggle, for a sum of dollars, it would be an absurdity of leaving ourselves into the yoke of the imperialists' slavery, which would finally end up in national ruin. This was eloquently proved by the crumbling of the East European nations that had built an economy dependent on other countries without any belief in their own power before capitalism revived with the bankruptcy of the global socialist market.

Our people adopted the building of an independent national economy as the main direction of economic construction under the guidance of the WPK, secondly because they had a plan of building up a powerful national economy that is developed in an all-round way.

Due to the 40-odd-year-long colonial rule of the Japanese imperialists and the three-year-long war the economic foundations of our country were in a deplorable condition. In such an environment it was a formidable task to build a powerful national economy developed many-sidedly. And yet, if efforts had been concentrated in a few fields alone and let the overall economy rely on them, it would have entailed a deformity and subordination in the economic development. It was obvious that only when an all-sided and all-inclusive economic structure and the proportionate balance were maintained between the sector of manufacturing means of production and the sector of manufacturing consumer goods, between the industrial and agricultural fields and their subdivisions, between production and transport, and between other economic and productive elements, would it be possible to set up organic links between production and consumption for a high tempo of economic development.

Of course, it is not an easy job to establish an all-sided and comprehensive economic structure and develop it with one's own efforts and technology, which would require a huge sum of initial investment - a limited supply of technology and resources might be a problem as well. Still, if strenuous efforts are made to lay the economic structure on the principle of developing heavy industry preferentially while developing light industry and agriculture simultaneously, equip the national economy with modern technology and establish bases of power, materials and fuel to suit the specific conditions, it is feasible to construct a self-reliant economy, versatile and powerful, serving the people of a given country.

Our people have maintained the building of an independent national economy as the main direction of economic construction under the leadership of the WPK because they knew that objective conditions can be brought to positive and favourable use in every job only when the internal force is overwhelming. If the internal force is weak, it is impossible to take advantage of even a favourable objective environment. And the reliable internal force makes it possible to make the most of the objective condition, however disadvantageous it might be.

In the years after the war when they had to rehabilitate the ravaged economy, our people laid the foundations of a self-reliant economy in the spirit of self-reliance firmly believing in their own efforts. At the time the big-power chauvinists were reluctant to agree on our country's building of an independent economy while the worshippers of big powers found fault with the economic policy pinning their hope on the "aid" from big powers. Our people, however, pushed ahead with the postwar rehabilitation and construction and laid down the foundations of an independent economy under the wise guidance of President Kim Il Sung. As the doctor would not give an injection to a dead body, no one would give any aid to those who could hardly run the economy by themselves. Keeping this stand, our people rose up from the war debris and steadily established the foundations of a 
self-reliant economy with their own efforts.

Since they developed the economy with the emphasis on the effort to create their own economic potentialities, our people opened the Chollima era in the economic development by taking advantage of the favourable objective environment of the global socialist market; since they have built an independent economy, they are now creating the era of Mallima, marching vigorously toward the final victory of the building of an economic giant without any vacillation even in the historic whirl of the bankruptcy of the global socialist market and the tenacious blockade and stifling isolation of the imperialist allied forces.

To build a self-reliant economy by applying the principles of the Juche idea does not mean ignoring or rejecting economic cooperation and exchange with other countries. The independent national economy we are building has nothing to do with the "isolationism" or "closed economy." Building an independent national economy does not mean an economy producing and supplying everything by itself. It is a fundamental requirement for the building of an independent national economy to produce and supply by our country's own efforts a greater volume (at least 60 - 70 percent) of major things needed for and greatly demanded in developing the national economy and improving the people's living standard, while obtaining, through foreign economic relations like international trade, crude rubber, oil and other materials that our country is devoid or short of.

The modern capitalist world is ruled by Ricardo's theory on international trade in the practical trade activities. The theory recommends that countries follow the line of engaging in production of "comparative advantage" things of their own and exchange them through international trade. This argument may be referred to as an extension of the superiority of specialization to the international system of specialization and international trade. But the superiority of specialization is not to be seen as constant since the interest of each nation is different and their level of economic development is also different from each other. This kind of contradiction finds its intensive expression in the trade relations between the developing nations and the developed capitalist nations. Proceeding from their interest the developed capitalist nations try to leave the developing countries as their sales market, object of capital investment and supplier of raw materials in every way. Meanwhile, those developing countries that have not yet attained economic independence want to purchase modern electronic and electric appliances, processed goods and other things from developed capitalist countries. In view of the theory on international trade, the developing countries have "comparative advantage" in agricultural production and the extractive sector, which need less processing, as they are of relatively less "opportunity cost." Meanwhile, the developed capitalist countries have got "comparative advantage" in processing industries and service industry which are of higher technical standards and of greater productivity. This makes the developing nations remain as backward agricultural nations or settle in industries that are of technically low level, bringing about socio-economic difficulties like depletion of resources and environmental destruction. On the contrary, the developed nations retain their predominance in trade using their superiority in the industries of intensive technology and knowledge. This phenomenon inevitably increases the gap between the developing countries and the developed countries in the level of economic development, which tends to reduce the developing countries to the victim of "globalization" and the economic appendage of imperialism.

Needless to say, in order to take a position in the lead of the developed nations it is necessary to channel big investment in the fields that are essential to the development of the national economy and the improvement of the living standards of the people, including the processing industry, even if they are of high "opportunity cost." In the course of making concentrated investment in those fields, the initially high "opportunity cost" gradually dwindles, changing the international economic structure and improving the international trade structure. This shows that the building of a self-reliant economy is a fundamental guarantee for establishment of a new international economic order and diversified and equal economic exchange with foreign nations.

\section{Great Vitality of a Self-Reliant Economy}

At present the world is being reduced to a stage of aggression and war, domination and subjugation owing to the imperialist powers including the US that holds advanced technology and purse in one hand and nuclear weapons in the other. As they were not economically self-sufficient, Iraq, Afghanistan and other Middle Eastern countries knelt down to the US imperialists without putting up any fight. Although they have a rich stock of natural resources and talented personnel, they are suffering from a new tragedy called the "crisis of refugees" because they are unable to make the most of the resources and personnel. Some nations, scared at the imperialist pressure and blockade for a certain period of time, pulled down the banner of independence and fell into the trap of subjugation leaving their destiny at the mercy of foreign forces.

But the socialist Korea, the land of Juche, has built a Juche-based industry, an independent national economy, with all its efforts, its belt tightened, in the revolutionary spirit of self-reliance. The economy has displayed its great vitality to the full.

The vitality of the independent national economy finds its expression, first of all, in the socialist economic construction going ahead in our own way as we want. We have never tried to imitate others or had a regard for their feelings in economic building. We have built the economy in our own way by relying on our own efforts. In the period of postwar rehabilitation and construction we made and used in lorry-mounted cranes which other countries offered to sell at the double price of the lorry, manufactured heavy-duty water pumps for irrigation projects by our own efforts, and made 
motor vehicles and tractors of our own model and designs, thus hastening economic construction successfully. In the 1960 s, when socialist construction was in full swing, the strain in transport was also eased by making electric locomotives of our own style. It was quite a task to make electric locomotives which were the monopoly of a few countries. A foreign ambassador to Korea went so far as to say that he would eat his hat if the Koreans made an electric locomotive. Nevertheless, our heroic working class successfully manufactured in a span of two years the electric locomotive which was made of as many as 180000 parts and weighed 120 tons and named it Pulgungi (red flag) reflecting the revolutionary spirit of the Korean people. The West Sea Barrage which we built across the $8 \mathrm{~km}$-wide rough sea with our own efforts and technology at the colossal cost of 4 billion US dollars is another gigantic product of our independent national economy. Shattering the imperialists moves of sanctions and isolation with the hammer of self-reliance, the Juche iron, Juche fertilizer and Juche fibre were mass-produced to the pleasure of all our people.

The enormous potentialities and great vitality of the independent national economy are becoming more conspicuous to the wonder of all the people around the world. Some of the eloquent proof of the potentialities and power of our independent economy are: CNC-equipped machines developed with our own efforts while shaping the cutting-edge technology, subway cars and light planes of a 100 percent Korean make, manufacture and launch of several artificial earth satellites which represent the complex of the nation's economic potentialities and the cream of modern science and technology, and nuclear weapons which are a powerful deterrent. All these achievements are attributable not to any assistance from any powers or blessing of God, but to the display of the revolutionary spirit of self-reliance in the economic building.

The great vitality of the independent national economy finds its expression also in the fact that our country is developing the economy proactively and securely without any vacillation despite the imperialists' scheme of stifling sanctions and isolation and successive economic upheavals of the world.

Our country has pushed ahead with economic construction always in the rigours of the uninterrupted sanctions and isolation applied by the imperialists. From the 1950 s to the mid-1990s it suffered from the sanctions and pressure from the Coordinating Committee for Export to Communist Area (COCOM) which comprised the NATO members including the US, and later from the Wassenaar Arrangement which is a worse version of the export control. In recent years the imperialists have resorted to all possible means of sanctions finding fault with the launch of artificial earth satellites, underground nuclear tests and the first H-bomb test which belong to the lawful rights and self-defensive policy of our country. The more ferocious the imperialists' sanction and suffocation policy became, the more fully we displayed the revolutionary spirit of self-reliance in accelerating economic construction, and now we are just around the corner of the final victory of the building of an economic giant.
The vitality of the independent national economy finds its clear expression in the fact that economic construction is making headway without vacillation, totally unaffected by the capitalist economic crises of all forms. The capitalist market economy is always accompanied by economic crisis for its intrinsic contradiction and weakness. Now that the contradiction of the capitalist market economy has reached the extremes there are incessant economic chaos and crises of all hues, including the circulatory crisis, financial crisis, monetary crisis, oil crisis and food crisis. Due to the internationalization of capital, the national economies around the world are closely connected, so the crisis in a certain country has a critical effect on the global economy as a whole.

In order to avoid the serious vicissitudes of the global economy and ensure a secure and safe development of the national economy it is essential to build an independent national economy which develops with the nation's own efforts, technology and resources. This principle turned out correct through the practices of our country when it made successful economic development without being affected from the global economic crises, such as the petroleum crisis in the 1970s, the global economic depression in the 1980s, and the spontaneous financial crisis involving the East Asian financial crisis in the 1990s.

The great vitality of the independent national economy finds another expression in that our powerful self-sufficient economy offers the material guarantee for peace and security in the Korean peninsula and the rest of the world. An independent national economy is an important guarantee of self-reliant defence capabilities. Unlike the capitalist armed forces whose mission is to invade other countries, the fundamental aim of the building of armed forces in socialist society is to ensure self-reliance in national defence.

To keep the principle of self-reliance in national defence means defending one's country with one's own capabilities. The US and other imperialists, based on the theory of "omnipotence of weapons," are now threatening and blackmailing other countries by wielding modern military hardware, and making huge profit through arms trade and exploitation of other nations. In this situation it is very important for the developing countries to create a defence industry of their own.[10, 11]

The principle of self-reliance in national defence is to be supported by a strong independent national economy in terms of material supply. Only when the nation's own defence industry is developed on the strength of the independent national economy will it be possible to develop different kinds of offensive and defensive weapons suited to the local conditions and environment, thus holding the initiative in the confrontation with the imperialists.

Our country was once a colony of imperialism and a battleground of big powers in the past because its armed forces were not strong enough. But now it has become a military giant powerful enough to cope with big powers. This is attributable to the inexhaustible potentialities of the defence industry which our people have built up, with their belt tightened, under the wise leadership of President Kim Il Sung, 
Chairman Kim Jong Il and our respected leader Kim Jong Un, and the defence industry itself is inconceivable apart from the independent national economy.

Now that we have attained powerful military forces inclusive of the righteous nuclear deterrent and even H-bombs, which belong to the self-defensive alternative of the sovereign nation, we are able to cope with any form of war chosen by the allied imperialist forces and defend the stability in the Korean peninsula and the global peace and security reliably.

\section{Conclusion}

Our people's struggle to build up an independent national economy in the spirit of self-reliance, is developing onto a higher level, powerfully driven by the self-development-first principle under the wise leadership of our respected leader Kim Jong Un.

Self-development means making oneself strong. In other words, it means building up one's own strength in one's own mode of struggle and creation, instead of seeking others' assistance. To maintain the self-development-first principle in economic construction is to have the steadfast idea that self-development is the best way to push ahead with economic construction and solve all problems arising in economic construction on the principle of self-development.

Self-development is the one and only motive force and powerful weapon that enable all our service personnel and people to rally firmly behind our respected leader Kim Jong Un and hit the great target of building an economic giant. With the belief in self-development we have thwarted the imperialists' suffocating moves of sanctions and isolation, manufactured subway cars and light planes of our own style which are now in pleasant operation in the underground and sky, and even launched our own satellites into space, thus displaying the honour of our nation as never before in history. It is thanks to the principle of self-development that factories and enterprises are mushrooming equipped with latest technology, and completely home-made goods are being produced earning world fame. Monumental edifices have been erected in large numbers, which would be impossible for others even in dozens of years, so the appearance of our country is changing day by day and morning by evening. We have manufactured even $\mathrm{H}$-bombs on the enormous strength of the principle of self-development, and thus the complete victory in the effort to build a prosperous socialist country which has enormous power and where everything thrives and the people live as happily as anyone in the world, is near at hand.

Under the wise leadership of our great leaders the heroic Korean people have set a model of an independent economy for the world to learn from and won victory after victory under the banner of self-reliance. The history of our people's struggle reiterates the truth that we will be able to win greater victories and achievements when we hold fast to the self-development-first principle in the revolution and construction under the sagacious guidance of our respected leader Kim Jong Un.

Carrying forward the history and tradition of self-reliance and self-development we will surely win the final victory in building a prosperous socialist nation by further consolidating the foundations of the independent national economy we inherited from our great leaders.

\section{References}

[1] On the Juche idea-Democratic People's Republic of Korea www.korea-dpr.info/lib/.

[2] The Juche idea www.itkd.co.nz/reference/essays/.

[3] The Political Philosophy of Juche_Stanford University https://web.stanford.edu/group/sjeaa/journal3.

[4] Let Us Brilliantly Accomplish the Revolutionary Cause of Juche www.uk-songun.com/index.php.

[5] The Origin of the Juche www.kfausa.org/the-orgin-of-the-Juche-idea.

[6] Juche Idea Study Group of England https://www.facebook.com/Juche-idea-study-group-of-England.

[7] Juche idea and Development of Korea's Economy $\mathrm{http} / / / \mathrm{krld} . \mathrm{pl} / \mathrm{krld} /$ czytelniateksty/biuletyny/.

[8] Democratic People's Republic of Korea Constitution https://www.unodc.org/.

[9] Description: On the building of an independent national economy https://library.soas.ac.uk/record/442358.

[10] Pyongyang, January 1(KCNA)_Rodong Sinmun www.europarl.europa.eu/.

[11] Onward Towards the Final Victory! Arizona.openrepository.com/Arizona/bitstream/10150/320163 $/ 1$. 